\title{
LOAD BEARING RCC SHEAR WALL SYSTEM FOR TALL RESIDENTIAL BUILDINGS IN INDIA - A GLOBAL PERSPECTIVE ON MINIMUM WALL THICKNESS REQUIREMENTS
}

\author{
Amit Barde ${ }^{1}$ \\ ${ }^{1}$ Head - Precast Design, RBF - EDRC, Mumbai, Larsen \& Toubro Construction
}

\begin{abstract}
Through the last decade, India has seen unprecedented developmental changes with rising standard of living amongst the masses. Significant and sustained increase in housing demand, coupled with considerable shrinkage in skilled workforce, have challenged the construction industry with sizeable shortfall of housing units. The recently announced "Housing for All by 2022" campaign by the Indian Government has also put additional pressure on the construction industry to deliver projects in record time frames. Traditionally, residential houses in major cities of India have been multi-storied high-rise apartments suitable for modular construction. Modular construction using Load Bearing Shear Wall (LBSW) System with rapid construction methodologies such as Aluminium/Tunnel Formwork or Precast Concrete fits perfectly as an alternative for traditional construction with shorter construction duration and reduction in labor, while exceeding quality standards of conventional construction practices in India. Thus, LBSW is system is becoming increasingly popular for several tall buildings projects of Mass Housing in Metro as well as Tier 1 cities. This paper focuses on current guidelines for the minimum wall thickness for LBSW System in terms of structural design and Fire Resistance Rating (FRR). FRR requirements are looked at in more detail as these guidelines govern wall thickness requirements for Tall Buildings in the range of $70-100 \mathrm{~m}$ for LBSW Systems - typical height range for Mass Housing projects. FRR provisions of International Codes are compared to IS Code provisions. In the interest of economical design of LBSW Buildings, it is proposed to adopt international FRR provisions without affecting the design intent and structural integrity of the building.
\end{abstract}

Keywords: Tall Residential Buildings, Mass Housing, Load Bearing Shear Wall System, Fire Resistance Rating, Minimum Wall Thickness

\section{BACKGROUND}

Tall Residential Buildings have been traditionally built using a beam/column moment frame system in India over the last three-four decades. Generally the buildings have been 12-14 levels tall with the exception of Metro Cities. Thus, the mainstream RCC IS codes such as IS 456 and IS 13920 have been mostly used for the beam/column moment frame system as a primary system. Although these codes discuss design and detailing requirements for the shear walls and load bearing walls, typical projects so far have systems where a few walls are used in the overall framed system, whether load bearing or lateral load resisting shear walls (Refer Figure 1).

Recent construction methodology trends in the residential sector, however, have seen an unprecedented shift in the choice of structural system. This has been further fueled by end users' inclination towards improved productivity and efficiency, and supported by the technology advent in terms of state-of-the-art formwork systems such as Aluminum Formwork Systems, Tunnel Formwork System and Precast Large Concrete Panel (PLCP) systems; such systems have gained significant momentum in the industry over the last decade. At the core of all these technologies lies the RCC Load Bearing Shear Wall (LBSW) System that provides key advantages of faster completion and reduced workforce requirements, coupled with superior quality and low maintenance for residential buildings. The Indian Design Codes, however, have lagged behind in updates where such systems are addressed specifically for design requirements relevant to the technology. Even though structural design provisions of the existing codes still apply to the LBSW system,the structural integrity, serviceability and construction methodology requirements related to Fire Resistance Rating, Crack Control Measures, High Early Strength Concrete and Formwork Removal recommendations have not been updated in tandem with the global industry trends. In search of cost effective construction methodologies, the construction industry has therefore relied on adopting International Codal Provisions for, at least, the parameters that are independent of the geographical locations or design loads. In fact, in cases where the Indian Design Codes do not specifically address any particular design criteria or system, leading 
International Codes such as IBC, ACI and ASCE have been referred to, with appropriate approvals from premier educational institutes in India to validate such adoptions. The minimum wall thickness for RCC walls required as per the specified FRR for tall buildings using LBSW system is one such critical parameter that needs attention.

As noted above, although the RCC LBSW System has been a popular choice in recent years, the Indian Design Codes do not specifically include codal requirements for the system based on the efficiency and redundancy provided by the system. In general guidelines provided by the RCC codes, mainly IS 456 and IS 13920 are followed. While these codes are best fit for overall structural design approach, the empirical and/or nominal provisions of these codes greatly impact various other parameters beyond the structural design parameters. For instance, for a typical high-rise building (at $70 \mathrm{~m}$ or less above ground), a 2 HR FRR is required by the Mumbai Chief Fire Officer (CFO)- as per the Fire No Objection Certificate (NOC) received for recent projects under construction in Mumbai). The same FRR is revised to 3HR by the Mumbai High Rise Committee (HRC) (as per the CFO recommendation in the 2011 Mumbai HRC Draft Guidelines) for High-Rise buildings taller than $70 \mathrm{~m}$ above ground. Thus, in general, for buildings less than $70 \mathrm{~m}$ tall, a $160 \mathrm{~mm}$ minimum wall thickness is sufficient for both structural demand as well asthe fire resistance rating demand. Whereas, in buildings taller than $70 \mathrm{~m}$, the minimum wall thickness needed for 3 HR fire resistance rating becomes $200 \mathrm{~mm}$ (with 0.4 to $1 \%$ steel range) even if the structural design demand for RCC LBSW System could be $160 \mathrm{~mm}$ thick walls. This usually is not observed in the conventional system, as $200 \mathrm{~mm}$ thick walls are anyway provided (since fewer walls take the overall lateral load) even based on the Structural Design demand. Moreover, for RCC LBSW System buildings more than $100 \mathrm{~m}$ tall, the wall thickness demand based on structural design considerations also becomes $200 \mathrm{~mm}$ or more and thus matches with the FRR consideration thickness. Thus, in general, buildings in the range of 70 to $100 \mathrm{~m}$ only have the wall thickness controlled by Fire Resistance Rating instead of Structural demand and need additional attention in the interest of economical design.

\section{OBJECTIVE}

The primary objective of this paper is to compare the minimum wall thickness provisions of IS 456 and IS 13920 to similar provisions of International Codes. Based on the information provided, the intent is to propose adoption of minimum $160 \mathrm{~mm}$ thick walls in RCC LBSW System for 3HR Fire Resistance rating. The proposed adoption is based on the International Building Code - 2015 and Eurocode 2 requirements for RCC Walls and similar information provided by $\mathrm{ACI}$ and PCI publications. Individual structures will then be analysed for required/optimum wall thickness based on structural design demand.

\section{REFERRED CODES}

\subsection{Indian Codes}

1. IS $456-2000^{[1]}$

2. IS $13920-1993^{[2]}$

3. CED 38 - WC - Draft Standard Criteria for Structural Safety of Tall Buildings ${ }^{[3]}$

\subsection{International Codes}

1. IBC $2012^{[4]}$

2. ACI $318-2014^{[5]}$

3. PCI Design Handbook 7 th Edition $^{[6]}$

4. Eurocode 2 (BS EN 1992) ${ }^{[7]}$

\section{RCC LOAD BEARING SHEAR WALL (LBSW) SYSTEM}

The key difference between the conventional framed system (with or without shear wall system) and the RCC LBSW system is the significant inclusion of more load bearing walls. Figure 1 shows a typical floor plan of a conventional system and the same when adopted by the RCC LBSW system indicating the wall percentage. Generally, the conventional system will have $10-15 \%$ of load bearing walls. Whereas, the RCC LBSW system will typically have $70-80 \%$ load bearing walls (and as high as $95-98 \%$ of walls in a few cases). Thus, the RCC LBSW system has an inherent redundancy in the system compared to the conventional system in terms of load path to transfer gravity or lateral loads. Overall gravity loads are also evenly distributed where the system has rarely any members that carry significantly larger loads compared to other gravity load bearing members. Due to the presence of longer walls with higher stiffness in response to lateral loads, a welldetailed RCC LBSW system provides exceptional rigid buildings at satisfactory ductility. Several structures with RCC LBSW System have performed exceptionally well around the world during times of natural calamities by providing the expected structural integrity and life safety.

\section{PREVALENT INDIAN DESIGN CODE REQUIREMENTS OF MINIMUM WALL THICKNESS OF RCC WALL}

\subsection{For Specified Fire Resistance Rating}

IS 456 - 2000:For RCC structures, IS 456 provides minimum wall thickness requirements based on the specified Fire Resistance Rating. Figure 2 indicates the current requirements for specified FRR. 


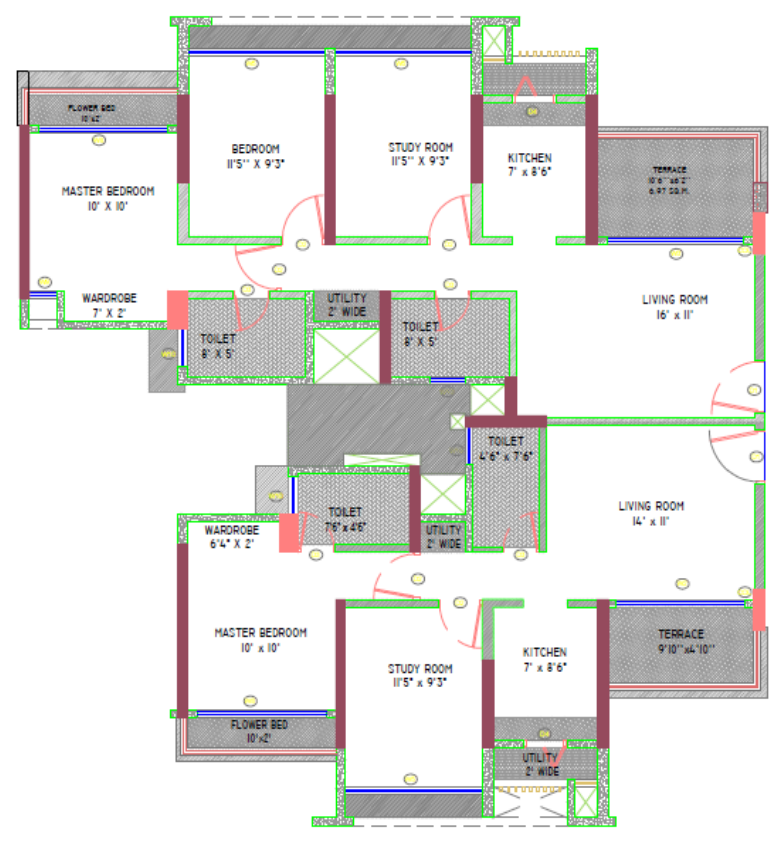

Conventional Beam/Column Frame System w/

Shear Walls Shear Wall Length - 29.3 m (0.18 $\mathbf{m} / \mathbf{s q m}$ )

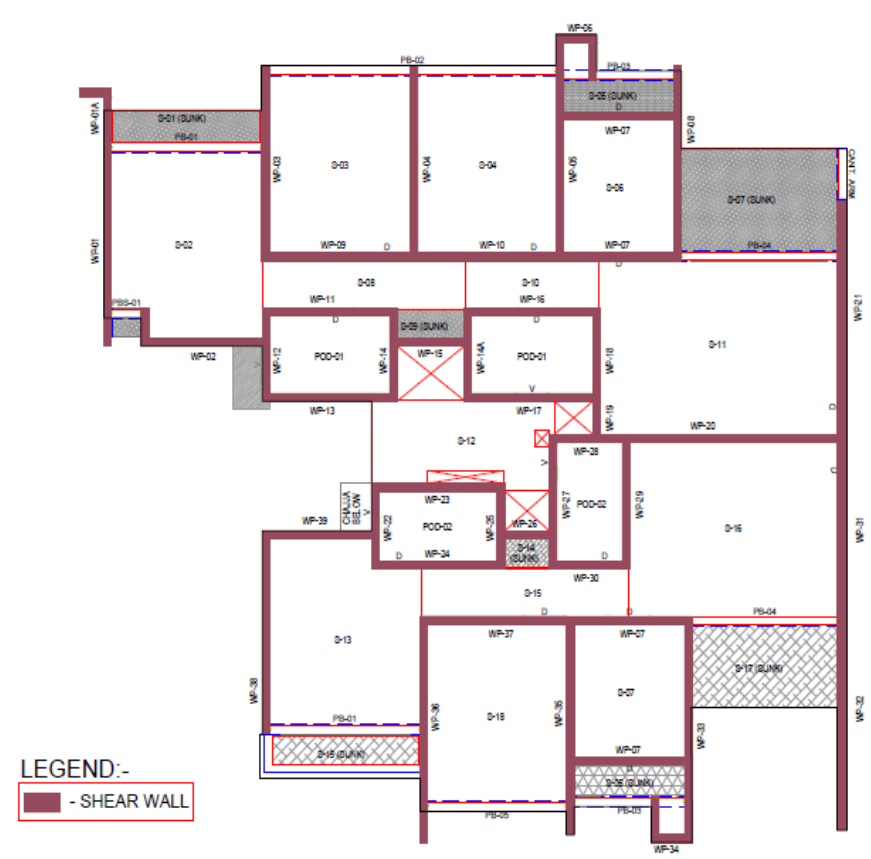

Load Bearing Shear Wall System

Shear Wall Length $-134 \mathrm{~m}(0.78 \mathrm{~m} / \mathrm{sqm})$

Note: Only a portion of the building floor plateis shown and compared for clarity

Fig-1:Comparison between Conventional Beam/Column Frames with Shear Wall System vs. LBSW System

\begin{tabular}{|c|c|c|c|c|c|c|c|c|c|}
\hline \multirow[b]{2}{*}{$\begin{array}{l}\text { Fire } \\
\text { Resis- } \\
\text { tance } \\
\quad h\end{array}$} & \multirow[b]{2}{*}{$\begin{array}{c}\text { Minimum } \\
\text { Beam } \\
\text { Width } \\
b\end{array}$} & \multirow{3}{*}{$\begin{array}{c}\text { Rib } \\
\text { Width } \\
\text { of Slabs } \\
b_{w} \\
\mathrm{~mm}\end{array}$} & \multirow{3}{*}{$\begin{array}{c}\text { Minimum } \\
\text { Thickness } \\
\text { of Floors } \\
\text { D } \\
\text { mm }\end{array}$} & \multicolumn{3}{|c|}{ Column Dimension ( $b$ or $D$ ) } & \multicolumn{3}{|c|}{ Minimum Wall Thickness } \\
\hline & & & & $\begin{array}{l}\text { Fully } \\
\text { Exposed }\end{array}$ & $\begin{array}{l}50 \% \\
\text { Exposed }\end{array}$ & $\begin{array}{c}\text { One } \\
\text { Face } \\
\text { Exposed }\end{array}$ & $p<0.4 \%$ & $0.4 \% \leq p \leq 1 \%$ & $p>1 \%$ \\
\hline & $\mathrm{mm}$ & & & $\mathrm{mm}$ & mm & mm & mm & mm & mm \\
\hline 0.5 & 200 & 125 & 75 & 150 & 125 & 100 & 150 & 100 & 100 \\
\hline 1 & 200 & 125 & 95 & 200 & 160 & 120 & 150 & 120 & 100 \\
\hline 1.5 & 200 & 125 & 110 & 250 & 200 & 140 & 175 & 140 & 100 \\
\hline 2 & 200 & 125 & 125 & 300 & 200 & 160 & - & 160 & 100 \\
\hline 3 & 240 & 150 & 150 & 400 & 300 & 200 & - & 200 & 150 \\
\hline 4 & 280 & 175 & 170 & 450 & 350 & 240 & - & 240 & 180 \\
\hline \multicolumn{10}{|c|}{ NOTES } \\
\hline \multicolumn{10}{|c|}{$\begin{array}{l}1 \text { These minimum dimensions relate specifically to the covers given in Table } 16 \mathrm{~A} \text {. } \\
2 p \text { is the percentage of steel reinforcement. }\end{array}$} \\
\hline
\end{tabular}

Fig - 2: IS 456 - Fig. 1 on Page 34 - Minimum Dimensions of RCC Members for Fire Resistance

Based on typical design considerations for high-rise buildings in the range of $70-100 \mathrm{~m}$, the reinforcement requirement in the walls generally ranges from $0.25 \%-$ $0.8 \%$ except for the base level walls of the first few floors. Thus, considerations for a reinforcement ratio of $0.4-1.0 \%$ are looked at. For 2 HR FRR, minimum wall thickness is noted at $160 \mathrm{~mm}$. Whereas, for $3 \mathrm{HR}$ FRR, the minimum thickness needed is $200 \mathrm{~mm}$. Figure 3 notes the related minimum cover requirements. Cover requirements specific to RCC walls, however, are not noted. Provisions as noted in Section 26.4.2.1 for walls $200 \mathrm{~mm}$ thick or less are followed. 


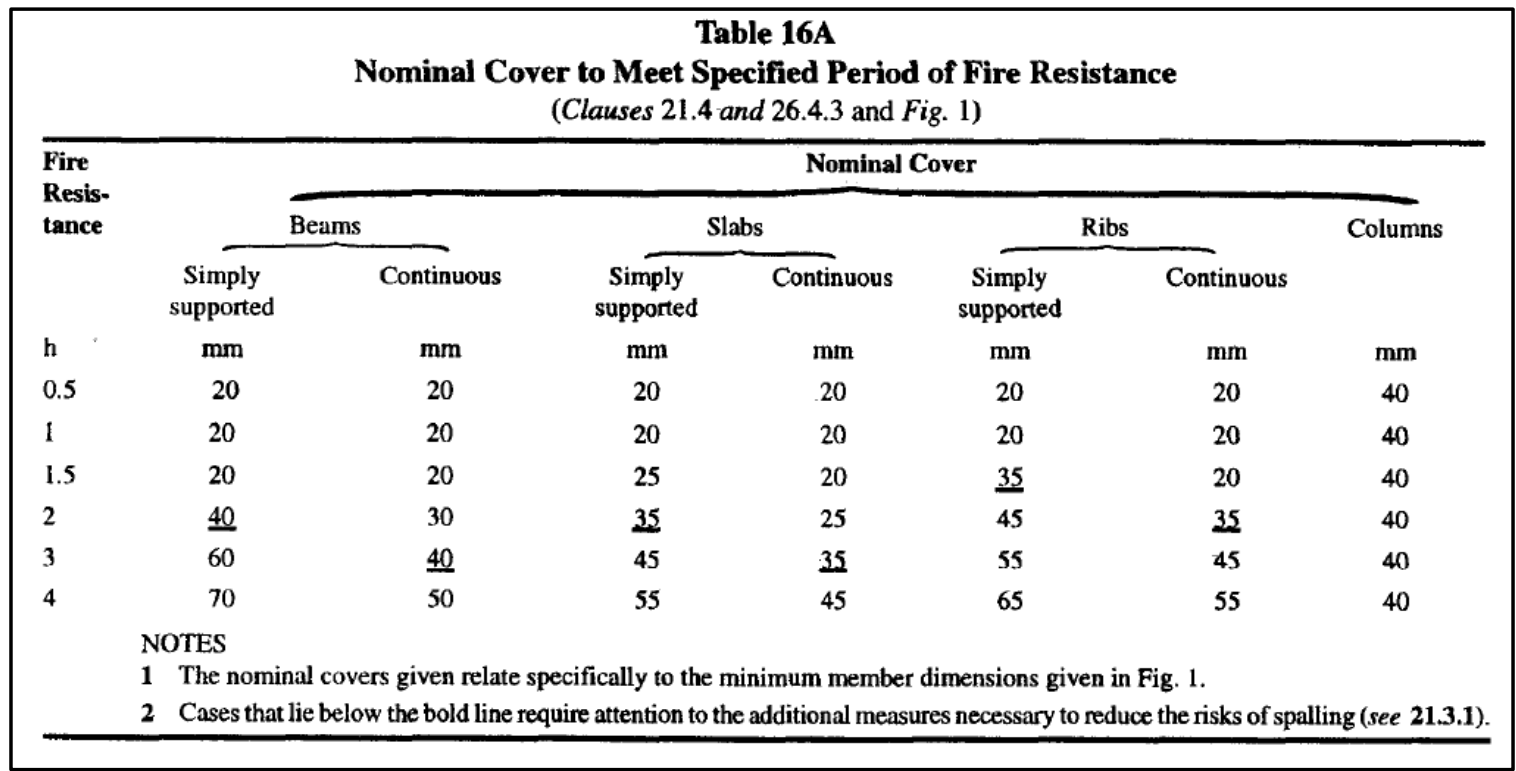

Fig - 3:IS 456 - Table 16A on Page 47 - Nominal Cover in RCC Members for Fire Resistance

\subsection{Minimum Wall Thickness per Structural Design}

\section{Guidelines}

IS 456- 2000: Section 32.2.3, Page 61 (Figure 4) specifies the minimum wall thickness for RCC Shear Walls. For a typical floor to floor height of $2900 \mathrm{~mm}$, the minimum wall thickness is calculated at $96.67 \mathrm{~mm}$ (considering no fixity).

\subsubsection{Maximum Effective Height to Thickness Ratio \\ The ratio of effective height to thickness, $H_{\text {we }} / t$ shall not exceed 30.}

Fig. 4: IS 456 - Section 32 - Minimum Thickness for RCC Walls

IS 13920 - 2004:For structures in Seismic Zone 3 and above, IS 13920 applies for achieving appropriate ductility. For LBSW, Section 9.1.2 (Figure 5) recommends minimum thickness of $150 \mathrm{~mm}$ based on structural requirements for buildings in high seismic zones.

IS CED 38 (Draft - IS - Code of Practice for Design of Tall Buildings): The draft IS code CED 38, which isto be released shortly (in wide circulation for comments), provides guidelines for tall buildings in the range of $45 \mathrm{~m}$ to $250 \mathrm{~m}$ in height. The code is being specifically prepared to bridge the gaps between IS 456 provisions and specific requirements, as per the Tall Building design considerations. The code, however, only addresses structural design considerations. In the proposed code, the IS 456 guidelines are changed with increased requirement on thickness of walls. Per section 8.5.1 (Figure 6), for a typical floor-tofloor height of $2900 \mathrm{~mm}$, the minimum thickness of structural RCC wall is calculated at $145 \mathrm{~mm}$ (considering no fixity). Thus, the minimum thickness of $160 \mathrm{~mm}$ governs even for tall buildings. Only for buildings in very high seismic zones (Zones IV and V), a minimum thickness of $160 \mathrm{~mm}$ is revised to $200 \mathrm{~mm}$, as per Section 8.5.14 (Figure $6)$.

\section{SHEAR WALLS \\ 9.1 General Requirements \\ 9.1.1 The requirements of this section apply to the shear walls, which are part of the lateral force resisting system of the structure. \\ 9.1.2 The thickness of any part of the wall shall preferably, not be less than $150 \mathrm{~mm}$.}

Fig. 5: IS 13920 - Section 9 - Minimum Thickness for RCC Walls

\subsection{Structural Wall Systems}

\subsubsection{The thickness of structural wall shall not be less than $160 \mathrm{~mm}$ or $\mathrm{H}_{\mathrm{w}} / 20$, whichever is larger.}

\subsubsection{Special requirements for Seismic Zone IV and Zone V}

(a) Structural walls shall be continuous to the base without being transferred in plane or out of plane at any level;

(b) The thickness of structural wall shall not be less than $200 \mathrm{~mm}$;

Fig. 6:CED 38 - Section 8.5 - Minimum Thickness for RCC Walls 


\section{INTERNATIONAL DESIGN CODE (IBC 2015) REQUIREMENTS OF MINIMUM WALL THICKNESS OF RCC WALL FOR SPECIFIED} FIRE RESISTANCE RATING:

The International Code Council (ICC) is a member-focused association. It is dedicated to developing model codes and standards used in the design, build and compliance process to construct safe, sustainable, affordable and resilient structures. Most U.S. communities and many global markets choose various International Codes that are published by ICC as the code of practice.

\section{About ICC}

http://www.iccsafe.org/

ICC - I Codes Adoption

http://www.iccsafe.org/international-code-adoptions/

The International Building Code (IBC) is published for residential and commercial buildings. This code is updated every three years. The current version is 2015 . However, the 2012 version is currently accepted industry-wide. The requirements for the FRR under considerations here are same in both versions. The code recommends both prescriptive as well as design specific approach. The prescriptive requirements are referred here as the FRR requirements in the IS 456 adopt the prescriptive approach. Chapter 7 of the IBC provides requirements for Fire and
Smoke Protection Features. Section 721 provides minimum thicknesses required for various building materials for specified FRR based on a prescriptive approach. Table 721.1(2) (Figure 7) specifies minimum thickness required at specified FRR for Walls and Partitions. For a 3 HR FRR, the minimum thickness of RCC wall, for Siliceous Aggregates, is noted at $6.2 \mathrm{in}(157.5 \mathrm{~mm})$.

Note: Footnote "i"of Table 721.1(2) requires that the RCC walls should be reinforced vertically and horizontally with temperature reinforcement as required by Chapter 19 Concrete (in turn referred to ACI 318 for the design requirements). Chapter 19 - Section 1905 also notes modifications to ACI 318. However, none of the modifications are related to the FRR. Thus, the structural design requirements (in terms of reinforcement provided and nominal covers) will be as per ACI 318 (Figure 8). ACI 318 requires the reinforcement provisions, as per gravity and lateral loads. ACI 318 - 2014, Chapter 11 specifies minimum reinforcement for Structural/Non Structural Walls.

In addition, Section 722 of Chapter 7 discusses the calculated fire resistance approach. Although, this approach is not in the scope of this paper, Section 722.2.1.1 (Figure 9) notes the minimum thickness of load bearing or non-load bearing walls in line with the discussion above.

\section{SECTION 721 PRESCRIPTIVE FIRE RESISTANCE}

\subsection{General.}

The provisions of this section contain prescriptive detail or assemblies. The materials of construction listed in Te to have the fire-resistance ratings prescribed therein. $\mathrm{W}$ dissipation are incorporated into a fire-resistance-rated shall be made available to the building official to show t reduced.

\section{TABLE 721.1(2) RATED FIRE-RESISTANCE PERIODS FOR VARIOUS WALLS AND PARTITIONS ${ }^{\mathrm{a}, 0, \mathrm{p}}$}

\begin{tabular}{|c|c|c|c|c|c|c|c|}
\hline \multirow[t]{2}{*}{ MATERIAL } & \multirow{2}{*}{$\begin{array}{c}\text { ITEM } \\
\text { NUMBER }\end{array}$} & & \multirow[t]{2}{*}{ CONSTRUCTION } & \multicolumn{4}{|c|}{\begin{tabular}{|c} 
MINIMUM FINISHED \\
THICKNESS FACE-TO \\
FACE $^{\mathrm{b}}$ (inches)
\end{tabular}} \\
\hline & & & & \begin{tabular}{|c|}
4 \\
hours
\end{tabular} & $\begin{array}{ll}3 \\
a u r e\end{array}$ & $\begin{array}{c}2 \\
\text { hours }\end{array}$ & $\begin{array}{c}1 \\
\text { hour }\end{array}$ \\
\hline \multirow{4}{*}{ Solid concrete } & \multirow{4}{*}{$4-1.1$} & Silliceous aggregate concrete. & & 7.0 & 6.2 & 5.0 & 3.5 \\
\hline & & Canibourate aggregate concrete. & & 6.6 & 5.7 & 4.6 & 3.2 \\
\hline & & Sand-lightweight concrete. & & 5.4 & 4.6 & 3.8 & 2.7 \\
\hline & & Lightweight concrete. & & 5.1 & 4.4 & 3.6 & 2.5 \\
\hline
\end{tabular}

Fig. 7: IBC 2015 - Section 721 - Prescriptive FRR for Solid Concrete 


\section{6-Reinforcement limits}

11.6.1 If in-plane $V_{u} \leq 0.5 \phi V_{c}$, minimum $\rho_{t}$ and minimum $\boldsymbol{\rho}_{t}$ shall be in accordance with Table 11.6.1. These limits need not be satisfied if adequate strength and stability can be demonstrated by structural analysis.

Table 11.6.1-Minimum reinforcement for walls with in-plane $V_{u} \leq 0.5 \phi V_{c}$

\begin{tabular}{|c|c|c|c|c|c|}
\hline Wall type & $\begin{array}{c}\text { Type of nonprestressed } \\
\text { reinforcement }\end{array}$ & $\begin{array}{c}\text { Bar/wire } \\
\text { size }\end{array}$ & $f_{y}$, psi & $\begin{array}{c}\text { Minimum } \\
\text { longitudinal }^{[1]}, \rho_{l} \\
\end{array}$ & $\begin{array}{c}\text { Minimum } \\
\text { transverse, } \rho_{t}\end{array}$ \\
\hline \multirow{4}{*}{$\begin{array}{l}\text { Cast-in- } \\
\text { place }\end{array}$} & \multirow{3}{*}{ Deformed bars } & \multirow{2}{*}{$\leq$ No. 5} & $\geq 60,000$ & 0.0012 & 0.0020 \\
\hline & & & $<60,000$ & 0.0015 & 0.0025 \\
\hline & & $>$ No. 5 & Any & 0.0015 & 0.0025 \\
\hline & $\begin{array}{l}\text { Welded-wire } \\
\text { reinforcement }\end{array}$ & $\begin{array}{c}\leq \mathrm{W} 31 \text { or } \\
\text { D31 }\end{array}$ & Any & 0.0012 & 0.0020 \\
\hline Precast ${ }^{[2]}$ & $\begin{array}{l}\text { Deformed bars } \\
\text { or welded-wire } \\
\text { reinforcement }\end{array}$ & Any & Any & 0.0010 & 0.0010 \\
\hline
\end{tabular}

11.6.2 If in-plane $V_{u} \geq 0.5 \phi V_{c}$, (a) and (b) shall be satisfied:

(a) $\rho_{\ell}$ shall be at least the greater of the value calculated by Eq. (11.6.2) and 0.0025 , but need not exceed $\rho_{t}$ in accordance with Table 11.6.1.

$$
\rho_{\ell} \geq 0.0025+0.5\left(2.5-h_{\mathrm{w}} / \ell_{w}\right)\left(\rho_{t}-0.0025\right)
$$

(b) $\rho_{t}$ shall be at least 0.0025

Fig. 8: ACI 318 - 2014 - Section 11.6 - Minimum Reinforcement Provisions for Walls

TABLE 722.2.1.1 MINIMUM EQUIVALENT THICKNESS OF CAST-IN-PLACE OR PRECAST CONCRETE WALLS, LOAD-BEARING OR NONLOAD-BEARING

\begin{tabular}{|l|c|c|c|c|c|c|}
\hline \multirow{2}{*}{$\begin{array}{c}\text { CONCRETE } \\
\text { TYPE }\end{array}$} & \multicolumn{4}{|c|}{$\begin{array}{c}\text { MINIMUM SLAB THICKNESS (inches) } \\
\text { FOR FIRE-RESISTANCE RATING OF }\end{array}$} \\
\cline { 2 - 6 } & $\mathbf{1}$ hour $1{ }^{1}{ }_{2}$ hours & 2 hours & 3 hours & 4 hours \\
\hline \hline Siliceous & 3.5 & 4.3 & 5.0 & 6.2 & 7.0 \\
\hline Carnonate & 3.2 & 4.0 & 4.6 & 5.7 & 6.6 \\
\hline Sand-lightweight & 2.7 & 3.3 & 3.8 & 4.6 & 5.4 \\
\hline Lightweight & 2.5 & 3.1 & 3.6 & 4.4 & 5.1 \\
\hline
\end{tabular}

Fig. 9: IBC 2015 - Section 722 - Minimum Wall Thickness for LB/NLB Walls using Calculations Approach 
7. PRECAST/PRESTRESSED

CONCRETE INSTITUTE (PCI) HANDBOOK $7^{\text {TH }}$ EDITION REQUIREMENT OF MINIMUM WALL THICKNESS OF RCC WALL FOR SPECIFIED FIRE RESISTANCE RATING:

Precast Concrete Institute (PCI) has conducted several fire tests for various building systems over the years. Several of these test reports are used by the Underwriters Laboratory (UL) to issue listings. The tests were conducted as per ASTME119 with the Structural End Point, Flame Passage
End Point and Heat Transmission EndPoint criteria. It has been documented that several RCC systems that pass the Structural End Point and Flame Passage end Point criteria do not pass the Heat Transmission Criteria. Thus, for typical RCC members detailed for in service structural loads, the Heat Transmission End Point becomes the governing criteria. Chapter 10, Section 10.5 (Figure 10) provides the prescriptive criteria for the Heat Transmission Requirements for specified FRR.

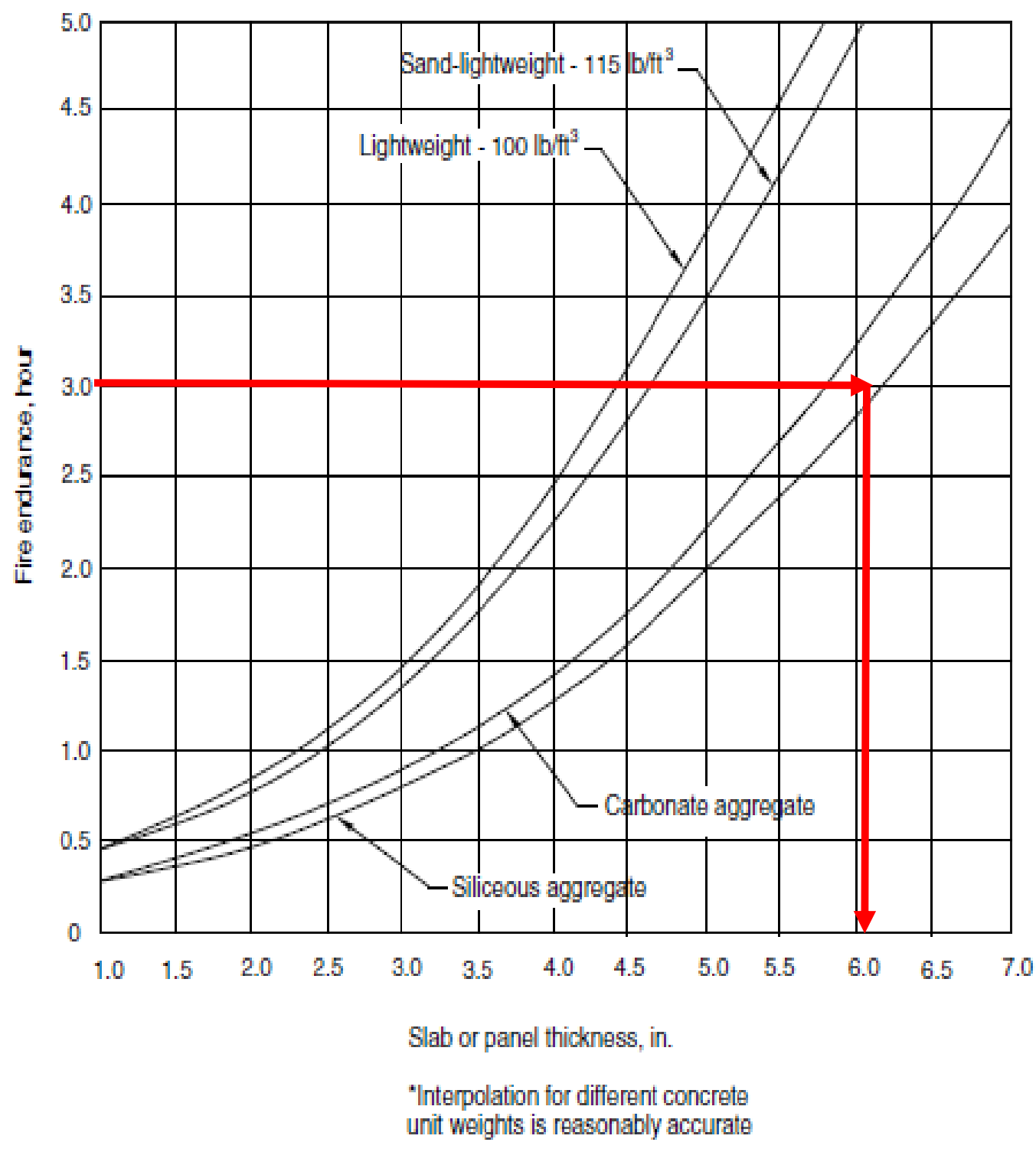

Fig. 10.5.1 Fire endurance (heat transmission) of concrete slabs or panels.

Fig. 10: PCI Design HB $7^{\text {th }}$ Edition - Section 10.5 - Minimum Thickness of RCC Elements for Specified FRR 


\section{EUROCODE 2 (BS EN1992) - REQUIREMENT} OF MINIMUM WALL THICKNESS OF RCC WALL FOR SPECIFIED FIRE RESISTANCE

\section{RATING:}

Eurocode 2 (BS EN 1992-1-2 (2004)) provides guidelines for fire resistance design of reinforced concrete structures. Similar to American codes, Eurocode 2 also requires primarily fire resistance against Load Bearing Function (R), Integrity Function (E) and Insulation Function (I) as noted in Sections 1.6 and 2.1.2. Criterion $\mathrm{R}$ is required for Mechanical Resistance under fire exposure and Criteria E and I are followed where compartmentation is required. Also, in general, Tabulated Data, Simplified Calculations and Advanced Calculations methods are followed as noted in Table 0.1 based on a Prescriptive or Performance Based approach, as per the project's requirement. Per Section 4.1, any of the above methods, within the given constraints, is acceptable. Thus, Simplified Method could be adopted over the Tabulated Data option, if it yields economical design.

Focusing on the scope of this paper, Section 5.4.1- Table 5.3 (Figure 11) specifies the minimum thickness required for Non-Load Bearing Walls for the E and I criteria. Although this table specifies the requirements for Non Load Bearing Walls, Section 5.2 (1) notes that the requirements noted in Table 5.3 will satisfy the E and I criteria for walls and slabs in general. In addition, the ratio of wall height to thickness is restricted to 40 to avoid excessive thermal deformation.

\begin{tabular}{|c|c|}
\hline $\begin{array}{c}\text { Standard } \\
\text { fire resistance }\end{array}$ & $\begin{array}{c}\text { Minimum wall thickness } \\
(\mathrm{mm})\end{array}$ \\
\hline 1 & 2 \\
\hline EI 30 & 60 \\
El 60 & 80 \\
El 90 & 100 \\
El 120 & 120 \\
\hline El 180 & 150 \\
\hline El 240 & 175 \\
\hline
\end{tabular}

Fig. 11: Eurocode 2 - Section 5.4 (Table 5.3) - Minimum Thickness of NLB Walls for Specified FRR

With respect to the Load Bearing (R) criterion, Section 5.4.2 (Figure 12) specifies the minimum thickness requirements for Load Bearing Walls. For typical residential buildings' requirements, per the provisions of this table, a minimum thickness of $210 \mathrm{~mm}$ and cover (from center of rebar) of 50 $\mathrm{mm}$ would be required for a 3 HR FRR. This is similar to the IS 456 requirements noted above $\left(\mu_{\mathrm{fi}}=0.7\right)$.

\begin{tabular}{|c|c|c|c|c|}
\hline \multirow[t]{3}{*}{$\begin{array}{l}\text { Standard } \\
\quad \text { fire } \\
\text { resistance }\end{array}$} & \multicolumn{4}{|c|}{$\begin{array}{c}\text { Minimum dimensions }(\mathrm{mm}) \\
\text { Wall thickness/axis distance for }\end{array}$} \\
\hline & \multicolumn{2}{|c|}{$\mu_{\mathrm{n}}=0,35$} & \multicolumn{2}{|c|}{$\mu_{f_{i}}=0,7$} \\
\hline & $\begin{array}{l}\text { wall exposed } \\
\text { on one side }\end{array}$ & $\begin{array}{l}\text { wall exposed } \\
\text { on two sides }\end{array}$ & $\begin{array}{l}\text { wall exposed } \\
\text { on one side }\end{array}$ & $\begin{array}{l}\text { wall exposed } \\
\text { on two sides }\end{array}$ \\
\hline 1 & 2 & 3 & 4 & 5 \\
\hline REI 30 & $100 / 10^{*}$ & $120 / 10^{*}$ & $120 / 10^{*}$ & $120 / 10^{*}$ \\
\hline REI 60 & $110 / 10^{*}$ & $120 / 10^{*}$ & $130 / 10^{*}$ & $140 / 10^{*}$ \\
\hline REI 90 & $120 / 20^{*}$ & $140 / 10^{\star}$ & $140 / 25$ & $170 / 25$ \\
\hline REI 120 & $150 / 25$ & $160 / 25$ & $160 / 35$ & $220 / 35$ \\
\hline REI 180 & $180 / 40$ & $200 / 45$ & $210 / 50$ & $270 / 55$ \\
\hline REI 240 & $230 / 55$ & $250 / 55$ & $270 / 60$ & $350 / 60$ \\
\hline
\end{tabular}

Fig. 12: Eurocode2 - Section 5.4 (Table 5.4) - Minimum Thickness of LB Walls for Specified FRR

It should be noted, however, that Eurocode 2 further allows adoption of Simplified and Advanced Calculations method here for Load Bearing criterion that could provide lower wall thickness based on the project specific calculations. The E and I criteria noted in Section 5.4.1 then governs as the minimum thickness criteria. This provision, over the years, has not been adopted by the IS codes, restricting the wall thickness requirements to the nominal provisions only.

\section{SUMMARY AND CONCLUSION}

The current residential construction industry is favoring RCC Load Bearing Shear Wall (LBSW) Construction in lieu of the conventional beam/column frame or local shear wall construction in recent years. The presence of considerably more shear walls is a key characteristic of the RCC LBSW system that results in a significant redundancy in the system to redistribute loads in the events of natural disasters. The RCC LBSW system, however, is not specifically addressed in the current IS 456 version and often gets compared to the Framed System with a few Shear Walls system. In addition to the redundancy offered by the RCC LBSW system, the overall structural design demand is also lesser for the Load Bearing Walls in the LBSW system, as compared to the Shear Walls in the framed system. Thus, in several cases, for buildings in the range of 70 to $100 \mathrm{~m}$ in height, the prevalent requirements of minimum wall thickness for specified Fire Resistance Rating (FRR) start governing in the LBSW system instead of structural design demand. In the interest of economical design, in such cases, it is proposed to refer to International Codal Provisions, namely, theInternational Building Code (IBC 2015) and Eurocode 2 (BS EN 1992) for the specified FRR that will still provide expected FRR performance and Structural Integrity. Table 1 summarizes the comparison of IS 456 provisions that are currently expected to be adopted by the RCC LBSW system for specified FRR vs. IBC 2015 and Eurocode 2 provisions for ready reference along with nominal structural minimum thickness provisions noted in Table 2. 
Table 1: Minimum RCC LB Wall Thickness Comparison based on 3 HR FRR Considerations

\begin{tabular}{|c|c|c|c|c|c|c|c|}
\hline \multicolumn{2}{|c|}{ IS456:2000 } & \multicolumn{2}{|c|}{ IBC2015 } & \multicolumn{2}{|c|}{$\begin{array}{l}\text { PCI Design Handbook } \\
7^{\text {th }} \text { Edition }\end{array}$} & \multicolumn{2}{|c|}{ Eurocode 2} \\
\hline $\begin{array}{c}\text { Clause } \\
\text { No. }\end{array}$ & Details & $\begin{array}{c}\text { Clause } \\
\text { No. }\end{array}$ & Details & $\begin{array}{c}\text { Clause } \\
\text { No. }\end{array}$ & Details & $\begin{array}{c}\text { Clause } \\
\text { No. }\end{array}$ & Details \\
\hline $\begin{array}{l}\text { Fig. } 1, \\
\text { Page } 34\end{array}$ & $\begin{array}{c}\text { Minimum } \\
\text { wall thickness } \\
\text { of } 200 \mathrm{~mm} \\
\text { with } 0.4 \% \\
\quad<p<1 \%\end{array}$ & $\begin{array}{c}\text { Table } \\
721.1(2)\end{array}$ & $\begin{array}{c}\text { Minimum } \\
\text { thickness = } \\
6.2 \text { inch = } \\
157.5 \mathrm{~mm}\end{array}$ & $\begin{array}{l}\text { Fig. } \\
10.5 .1\end{array}$ & $\begin{array}{c}\text { Minimum } \\
\text { thickness }=6.2 \\
\text { inch }=157.5 \\
\mathrm{~mm}\end{array}$ & $\begin{array}{c}5.4 .1 \\
5.4 .2 \\
4.2 \text { and } 4.3\end{array}$ & $\begin{array}{l}150 \mathrm{~mm} \text { for } \mathrm{E} \text { and } \mathrm{I} \\
210 \mathrm{~mm} \text { (50 mm cover) } \\
\text { for } \mathrm{R} \\
\text { Per calculation but not } \\
\text { less than } 150 \mathrm{~mm}\end{array}$ \\
\hline
\end{tabular}

Table 2: Minimum RCC LB Wall Thickness based on Structural Considerations - Indian Codes

\begin{tabular}{|c|c|c|c|c|c|}
\hline \multicolumn{2}{|r|}{ 456:2000 } & \multicolumn{2}{|r|}{ IS 13920} & \multicolumn{2}{|c|}{$\begin{array}{l}\text { Draft -Indian Standard Code of Practice of } \\
\text { Design of Tall Buildings (CED 38) }\end{array}$} \\
\hline $\begin{array}{l}\text { Clause } \\
\text { No. }\end{array}$ & Details & $\begin{array}{l}\text { Clause } \\
\text { No. }\end{array}$ & Details & $\begin{array}{l}\text { Clause } \\
\text { No. }\end{array}$ & Details \\
\hline \multirow[t]{2}{*}{32.2 .3} & \multirow{2}{*}{$\begin{array}{l}\text { Ratio of effective } \\
\text { height to thickness } \\
\mathrm{H}_{\text {we }} / \mathrm{t} \text { shall not } \\
\text { exceed } 30\end{array}$} & \multirow[t]{2}{*}{9.1 .2} & \multirow{2}{*}{$\begin{array}{l}\text { The thickness of any } \\
\text { part of the wall shall } \\
\text { preferably, not be less } \\
\text { than } 150 \mathrm{~mm}\end{array}$} & 8.5 .1 & $\begin{array}{c}\text { The thickness of structural wall shall not be } \\
\text { less than } 160 \mathrm{~mm} \text { or Hw/20, whichever is } \\
\text { larger. }\end{array}$ \\
\hline & & & & 8.5 .14 & $\begin{array}{l}\text { For seismic zone IV and V, The thickness of } \\
\text { structural wall shall not be less than } 200 \mathrm{~mm}\end{array}$ \\
\hline
\end{tabular}

\section{REFERENCES}

[1]-IS: 456 - 2000 - Code of Practice for Plain and Reinforced Concrete, Bureau of Indian Standards.

[2]-IS:13920-1993-Ductile Detailing of Reinforced Concrete Structures Subjected to Seismic Forces - Code of Practice, Bureau of Indian Standards

[3]-CED 38 (10639) WC - Draft Standard Criteria for Structural Safety of Tall Buildings

[4]- IBC 2015 - International Building Code, ICC

[5]- ACI 318-2014 - Building Code Requirements for Structural Concrete

[6]- PCI Design Handbook $7^{\text {th }}$ Edition - Precast/Prestressed Concrete, Precast/Prestressed Concrete Institute, USA

[7]-Eurocode 2 (BS EN 1992-1-2) - Design of Concrete Structures-Part 1-2: General Rules - Structural Fire Design

\section{BIOGRAPHY}

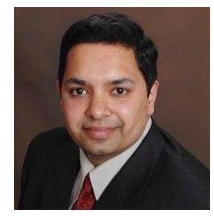

Mr. Amit Barde heads the Precast Design Group of the Residential Buildings Strategic Business Unit under the umbrella of Buildings \&Factories Independent Company of Larsen \& Toubro Ltd. Previously, he has worked with a leading precast concrete manufacturer in the United States for about ten years and has extensive experience in residential, commercial and industrial precast concrete structures. He has designed and managed several precast concrete projects such as data centers, office buildings, schools, warehouses, industrial plants, stadiums and parking structures. $\mathrm{He}$ graduated from Purdue University with Master's Degree in Civil Engineering. He is a Registered Professional Engineer (MI-USA) and a LEED Certified Professional (USGBC). 